\title{
Analysis of Buffalo Market Setting in the State of Pará, Brazilian Amazon
}

\author{
Blenda Patrícia Damasceno de Oliveira
}

Federal University of Pará (UFPA), Master's student of the Post-graduate Program in Animal Science, Brazil

E-mail: blendapdo@hotmail.com

\section{Fabrício Khoury Rebello}

Federal Rural University of Amazon (UFRA), professor of the Post-graduate Program in Agronomy, Brazil

E-mail: fabriciorebello@hotmail.com

\section{Marcos Antônio Souza dos Santos}

Federal Rural University of Amazon (UFRA), professor of the Post-graduate Program in Agronomy, Brazil

E-mail:marcos.santos@ufra.edu.br

José de Brito Lourenço Junior

Federal University of Pará (UFPA), professor of the Post-graduate Program in Animal Science, Brazil

E-mail: joselourencojr@yahoo.com.br

Received: Apr. 2, 2020

doi:10.5296/jas.v8i3.16794
Accepted: Apr. 27, $2020 \quad$ Published: May 12, 2020

URL: https://doi.org/10.5296/jas.v8i3.16794

\begin{abstract}
The objective of this study was to analyze the structure and conjuncture of the buffalo breeding tendency in the state of Pará, in order to generate relevant information for decision-making of farmers involved in the activity, as well as to guide public policies to
\end{abstract}


stimulate the development sector of Pará's economy in Brazilian Amazon. The study was conducted using secondary data, collected from the Brazilian Institute of Geography and Statistics (IBGE) Ministry of Agriculture, Livestock and Supply (MAPA), Ministry of Development, Industry and Foreign Trade (MDIC), Getulio Vargas Foundation (FGV), Central Bank of Brazil (BACEN) and the Food and Agriculture Organization of the United Nations (FAO) on the herd, production, price and financing granted to buffalo breeding. The Brazilian buffalo herd is concentrated in the northern region of the country, with $66.15 \%$ of the total herd, particularly in the state of Pará, which participates with $37.90 \%$ of the Brazilian herd, constituting the largest producing state in Brazil. In this state, the activity is concentrated in the Marajó meso-regions and in the Lower Amazon. In addition, it was found that the volume of rural credit granted to buffalo herd projects, fluctuated from 1995 to 2015, concentrating in the period from 2004 to 2007, stimulated by the expansion of cattle raising at pasture due to Bovine Spongiform Encephalopathy (BSE), a disease triggered in Europe over that period.

Keywords: animal production. bubalus bubalis. livestock trade

\section{Introduction}

The domestic buffalo (Bubalus bubalis) is a native species from the Asian continent and taken to Africa, Europe, Oceania, and finally to America (Damé, 2006). Only in the late nineteenth century, small lots of buffalo, originating from Asia, Europe (Italy) and the Caribbean, were introduced in Brazil, initially more for its exoticism than for its productive characteristics (Bernardes, 2007).

The Brazilian buffalo herd is mainly concentrated in the northern region of the country, with $66.15 \%$ of the total herd distributed among the Mediterranean, Murrah, Jafarabadi and Carabao breeds (Lourenço Júnior; Garcia, 2008; IBGE, 2018). For the continuous sustainable use of this species, it is necessary to improve productivity and focus on the breeds conservation and improvement, as a global resource (Thiruvenkadan et al., 2013).

These animals show significant adaptability to different environmental conditions, high fertility and productive longevity, which allowed the buffalo breeding present high socioeconomic importance in Brazil.

In addition, the activity shows relevant production characteristics in relation to dairy production, because its nutritional value and industrial yield are considered better than the cow's milk. This food stands out for its high content of vitamins A, D and B2, low cholesterol, besides having $47 \%$ more protein and $14 \%$ more minerals than cow's milk, therefore, a higher yield of derivatives (butter, cheese and sweets). The meat is more nutritious and healthy than cow's meat, showing 40\% less cholesterol, 12 times less fat, 55\% less calories, $11 \%$ more protein and 10\% more minerals (Amaral; Escrivão, 2005).

The state of Pará holds the largest herd in Brazil, even though, buffalo ranching is a traditional activity, with low technological level. The activity stands out in both meat and milk production, which is the main raw material of traditional Marajó cheese. This product is typically from Pará, with potential for domestic and foreign markets. Besides that, it has a 
production protocol, established by the State Law on Handcrafted Products - Law 7.565, of 10/25/2011 (ADEPARÁ, 2011). This activity comprises a wide value chain involving aspects of gastronomy, tourism, handcrafts and other establishments types that commercialize the production.

Even so, several obstacles in relation to rational production and its profitability limit the activity. Among the limiting factors, it stands out the extensive system in large pastures adopted by most producers; the difficult access to most rural properties, which hinders the production flow; the lack of infrastructure in rural properties, which do not provide fences, making it difficult to control the agricultural production and techniques implementation, where animals feed on native pastures, that are poor in nutrients and minerals; lack of electricity, which is important for the milk and dairy products conservation, and, mainly, the lack of hygienic-sanitary control and herd mineral supplementation (Barbosa, 2005).

Thus, considering the "paraense" buffalo breeding representativeness in the national context, the persisting structural problems of productive structure and the challenges to be overcome, mainly in order to maximize the economic, social and cultural aspects - that involves the activity in "paraense" territory - it is necessary to identify the activity current scenario to reflect the required strategies to implement policies and initiatives to make buffalo breeding more promising in "paraense" economy.

In this context, this study analyzed the structure and market conjuncture of buffalo breeding in the state of Pará, in the Brazilian Amazon, as a way to contribute with information for decision-making of farmers involved in the activity, as well as to guide public policies to encourage the sector development in the "Paraense" economy.

\section{Material and Methods}

The study was conducted using secondary data, collected from the Brazilian Institute of Geography and Statistics (IBGE), Ministry of Agriculture, Livestock and Supply (MAPA), Ministry of Development, Industry and Foreign Trade (MDIC), Getulio Vargas Foundation (FGV), Central Bank of Brazil (BACEN) and the Food and Agriculture Organization of The United Nations (FAO).

The evolution of the variables behavior (production, productivity, price and credit) was performed by calculating the Geometric Annual Growth Rate estimated by linear regression, using the semi-logarithmic model, considering the statistical significance at 5\% probability level, according to Student's t-test (Negri Neto et al., 1993; Mendes; Padilha Junior 2007; Gujarati; Porter, 2011), expressed in equation 1 below. A detailed description of the statistical model can be found in the paper written by Raiol et al. (2009). The analyses will be developed for both meat and milk production.

$$
Y_{i t}=a_{i}+b_{i} T+\varepsilon_{i}
$$

Where:

Yit = natural logarithm of variable $\mathrm{i}$ in year $\mathrm{t}$; 
ai = mean value of the logarithmic variable $\mathrm{i}$;

bi = natural logarithm of growth rate $(1+i)$. Growth rate $i$ was calculated through the following formula: $\mathrm{i}=\mathrm{i}=[$ antiln bi $]-1$;

$\mathrm{T}=$ trend variable;

$\varepsilon \mathrm{t}=$ random error, which has zero mean and constant variance by hypothesis.

It was adjusted all monetary variables for July 2018, based on the General Price Index Internal Availability of Getulio Vargas Foundation (FGV, 2018). By using the deflated prices, the inflation effect is eliminated and price analysis is performed.

It was performed the calculation of the seasonal price index for the 2006-2018 period, according the following steps:

a) The price variable was deflated by the General Price Index (IGP-DI, July $2018=$ 100) of the FGV;

b) The 12-month centralized moving arithmetic average (MM), of the deflated prices, was calculated using the formula 2 proposed by Hoffmann (1991):

$$
M M_{t}=\frac{1}{12}\left(P_{t-6}+P_{t-5}+\ldots+P_{t}+P_{t+1}+\ldots+0,5 P_{t+5}\right)
$$

(c) the monthly seasonal indices were obtained by dividing the original monthly price series for buffalo meat by the corresponding moving average, as follows (formula 3 ):

$$
I E S_{i t}=\frac{P_{t}}{M M_{t}}=\frac{T_{t} x C_{t} x S_{t} x E_{t}}{T_{t} x C_{t}}=S_{t} x E_{t}
$$

Where IES $\mathrm{it}_{\mathrm{t}}$ is denominated the Simple Seasonal Index. $\mathrm{P}_{\mathrm{t}}$ is the price of the buffalo meat at month $t$, in Brazilian real per unit. $T_{t}$ is the time series trend in period $t . C_{t}$ is the cyclical variation of the time series in period $t$. $S_{t}$ is the seasonal variation of the time series in period $t$. Et is the random or irregular variation of the time series in period $t$.

The equations 1, 2 and 3, described above, were used to statistical treatment of research analysis, especially about the prices trend projection (Graph 2) and the price seasonal analysis (Graph 3). For tabulation, data analysis and graph composition, it was used Microsoft ${ }^{\circledR}$ Office Excel program, version 2010.

\section{Results}

\subsection{Characteristics of The Buffalo Breeding System in Pará}

Buffalo breeding in the Brazilian Amazon is, basically, carried out in pasture rearing systems, using four distinct pasture ecosystems: 1) native to the estuary's floodplains, distributed in the Marajó island, where most of the herd is concentrated; 2) native to floodplains, located in the Lower and Middle Amazon micro-regions; 3) native of dry land; and 4) cultivated in dry land 
in originally forest areas (Lourenço Junior; Garcia, 2008).

It is produced more productive and nutritive forage in dry land systems. In addition, the integrations between native and cultivated pastures are established in this system.

In the last decades, buffalo breeding in the Amazon has grown in view of its satisfactory profitability. This development generates income increase for the farmer, as well as jobs in the production chain segments (Lourenço Junior; Garcia, 2008).

The state of Pará accounts for $37.90 \%$ of the total buffalo herd in Brazil (Table 1). The state economy has increased by 0.76 per year in relation to 1996-2016 period.

Table 1. Growth rate of buffalo herd in Brazil, North region and in the state of Pará in 1996-2016 period

\begin{tabular}{l|c|c|ccc}
\hline $\begin{array}{l}\text { Brazil } \\
\text { North }\end{array}$ & $\begin{array}{c}\mathbf{2 0 1 6} \text { herd } \\
\text { Region } \\
\text { and Pará }\end{array}$ & (heads) & $(\boldsymbol{\%})$ & \multicolumn{3}{|c}{ Growth rate (\%) per year } \\
\cline { 3 - 5 } & & & $\mathbf{1 9 9 6 - 2 0 0 6}$ & $\mathbf{2 0 0 6}-\mathbf{2 0 1 6}$ & $\mathbf{1 9 9 6 - 2 0 1 6}$ \\
\hline Brazil & $1,370,941$ & 100.00 & $1.01^{*}$ & $1.71^{*}$ & $1.36^{*}$ \\
North & 906,867 & 66.15 & $1.00^{*}$ & $1.26^{*}$ & 1.77 \\
Pará & 519,586 & 37.90 & $0.39^{\mathrm{ns}}$ & $1.93^{*}$ & $0.76^{*}$ \\
\hline
\end{tabular}

Source: IBGE, 2018.

Observation: TGC -Growth Geometric Rate, in \% per year, estimated through linear regression. (*) Significant at 5\% probability; (ns) Not-significant.

In Pará, the buffalo herd is concentrated in the Marajó meso-regions and in the Lower Amazon. In Marajó, the most prominent microregion is Arari, with 354,023 buffaloes, comprising Cachoeira do Arari, Chaves, Muana, Ponta de Pedras, Salvaterra, Santa Cruz do Arari and Soure municipalities, which account for $68.14 \%$ of the herd in the state. In the Lower Amazon, the largest producing micro-regions of buffalo herd are Almeirim with 61,786 buffaloes (composed of Almeirim and Porto de Moz municipalities) and Santarém with 47,908 animals (composed of Alenquer, Belterra, Curuá, Mojuí dos Campos, Monte Alegre, Placas, Prainha and Santarém municipalities).

Table 2 shows that, among the microregions in Pará, Óbidos was the only one that showed a significant decrease in GGR, which may be related to sub-records of buffaloes in the region.

In addition, Table 2 shows that Itaituba, São Felix do Xingu, Parauapebas and Altamira micro-regions had the highest GGR in the state. Almerim stood out among the three largest producing meso-regions regarding increase of the herd, showing a growth rate of $3.79 \%$ per year over the analyzed period. Arari meso-region did not show any significant growth. 
Table 2. Distribution and growth of buffalo rearing in Pará microregions, 1996-2016

\begin{tabular}{l|c|c|c}
\hline Micro-region & $\begin{array}{c}\text { Buffalo herd } \\
\text { (heads) }\end{array}$ & $\mathbf{( \% )}$ & $\begin{array}{c}\text { GGR\% } \\
\mathbf{1 9 9 6} \mathbf{- 2 0 1 6}\end{array}$ \\
\hline Arari & 354,023 & 68.14 & $0.65^{\text {ns }}$ \\
Almerim & 61,786 & 11.89 & $3.79^{*}$ \\
Santarém & 47,908 & 9.22 & $0.66^{\text {ns }}$ \\
Furos de Breves & 9,081 & 1.75 & $4.24^{*}$ \\
Portel & 7,881 & 1.52 & $3.44^{*}$ \\
São Miguel do Guamá & 5,761 & 1.11 & $3.74^{*}$ \\
Bragantina & 4,843 & 0.93 & $0.46^{\text {ns }}$ \\
Tomé-Açu & 4,576 & 0.88 & $1.19^{*}$ \\
Óbidos & 4,394 & 0.84 & $-10.14^{*}$ \\
São Félix do Xingu & 2,916 & 0.56 & $9.33^{*}$ \\
Itaituba & 2,646 & 0.51 & $9.43^{*}$ \\
Altamira & 2,536 & 0.49 & $8.38^{*}$ \\
Conceição do Araguaia & 1,529 & 0.29 & $4.8^{*}$ \\
Redenção & 1,494 & 0.29 & $0.53^{*}$ \\
Cametá & 1,366 & 0.26 & $3.9^{*}$ \\
Castanhal & 1,342 & 0.26 & $2.8^{*}$ \\
Salgado & 1,258 & 0.24 & $0.45^{*}$ \\
Tucuruí & 1,234 & 0.24 & $5.47^{*}$ \\
Belém & 1,124 & 0.22 & $5.01^{\text {ns }}$ \\
Paragominas & 727 & 0.14 & $6.36^{*}$ \\
Parauapebas & 703 & 0.14 & $8.48^{*}$ \\
Marabá & 458 & 0.09 & $0.2^{*}$ \\
\hline
\end{tabular}

Source: research data from IBGE data, 2018.

Observation: GGR- Annual Geometric Growth Rate, in \% per year, estimated through linear regression. (*) Significant at 5\% probability; (ns)Non-significant.

The data in Table 3 shows the small farms representativeness in this activity, and those with less than 200 hectares of total area represent $67.91 \%$ of the total buffalo production units and concentrate $36.72 \%$ of the buffalo herd in Pará. Cattle ranches with more than 1,000 hectares are also prominent in the total state herd, although they represent only $6.87 \%$ of the total production units, accounting for $34.97 \%$ of the state herd.

It means that the buffalo herd in Pará is a small producers typical activity, most of which are extensively reared, that is, left in mostly native pastures, usually devoid of fences or with rudimentary fences (Barbosa, 2005). In addition, they are characterized by low use of technology or intensification and generally as a complementary activity to other breeding activities. 
Table 3. Number distribution of cattle ranches and buffalo herd according to total area group, state of Pará, 2006

\begin{tabular}{|c|c|c|c|c|}
\hline \multirow[t]{2}{*}{ Total area groups } & \multicolumn{2}{|c|}{ Ranches number } & \multicolumn{2}{|c|}{ Herd (heads) } \\
\hline & Quantity & $(\%)$ & Head & $(\%)$ \\
\hline Less than 10 ha & 784 & 17.41 & 36,826 & 9.91 \\
\hline 10 to less than 20 ha & 388 & 8.62 & 19,347 & 5.20 \\
\hline 20 to less than 50 ha & 641 & 14.24 & 23,011 & 6.19 \\
\hline 50 to less than 100 ha & 491 & 10.91 & 19,200 & 5.16 \\
\hline 100 to less than 200 ha & 753 & 16.73 & 38,152 & 10.26 \\
\hline 200 to less than 500 ha & 410 & 9.11 & 39,108 & 10.52 \\
\hline 500 to less than 1000 ha & 162 & 3.60 & 28,595 & 7.69 \\
\hline 1000 to less than 2500 ha & 139 & 3.09 & 36,478 & 9.81 \\
\hline 2500 to more & 170 & 3.78 & 93,543 & 25.16 \\
\hline Others & 564 & 12.53 & 37,480 & 10.08 \\
\hline Total & 4,502 & 100.00 & 371,740 & 100.00 \\
\hline
\end{tabular}

Source: IBGE data (2006).

Observation: Data in this table are the most current available as that information is not in the data disclosed in the 2017 Census so far.

Regarding the buffalo-milk producing ranches, it is realized that farmers without area up to less than 200 hectares of the total area represent $70.65 \%$ of the total milk production units, and concentrate $61.52 \%$ of the buffalo milk herd in the state (Table 4 ).

Table 4. Number distribution of livestock establishments and buffalo dairy herd, according to the total area groups, in the state of Pará, Brazil, 2017

\begin{tabular}{l|c|c|c|c}
\hline \multirow{2}{*}{ Total area groups } & \multicolumn{2}{|c|}{ Ranches number } & \multicolumn{2}{c}{ Herd (heads) } \\
\cline { 2 - 5 } & & & \multicolumn{1}{c}{$\begin{array}{c}\text { Milked } \\
\text { buffaloes }\end{array}$} & $(\boldsymbol{\%})$ \\
\hline Farm with no area & 51 & 3.55 & 336 & 1.52 \\
Less than 10 ha & 143 & 9.94 & 1,311 & 5.95 \\
From 10 to less than 20 ha & 79 & 5.49 & 982 & 4.46 \\
From 20 to less than 50 ha & 188 & 13.07 & 2,868 & 13.01 \\
From 50 to less than 100 ha & 257 & 17.87 & 3,406 & 15.46 \\
From 100 to less than 200 ha & 298 & 20.72 & 4,654 & 21.12 \\
From 200 to less than 500 ha & 236 & 16.41 & 4,309 & 19.55 \\
From 500 to less than 1000 ha & 87 & 6.05 & 1,890 & 8.58 \\
From 1000 to less than 2500 ha & 56 & 3.89 & 1,400 & 6.35 \\
From 2500 ha to less than 10 000 ha & 38 & 2.64 & 1,071 & 4.86 \\
From 10 000 to more & 5 & 0.35 & 206 & 0.93 \\
\hline Total & $\mathbf{1 , 4 3 8}$ & $\mathbf{1 0 0 . 0 0}$ & $\mathbf{2 2 , 0 3 8}$ & $\mathbf{1 0 0 . 0 0}$ \\
\hline
\end{tabular}

Source: data from IBGE (2018). 


\section{Macrothink}

Observation: Data directly obtained from IBGE Center - Belém, on September 162018.

Thus, it is evident that in Pará, the milk production is concentrated in small ranches, which still have extensive management characteristics and low productivity.

Table 5 shows that, although Pará has the largest buffalo herd in Brazil, the state represents only $14.06 \%$ of Brazilian milk production. This indicates that, although buffalo milk is a differentiated product with good nutritional qualities for the derivatives production, such as cheese, the activity is little explored in the state, showing that the herd in Pará is more specialized in meat production.

Table 5. Distribution of buffalo milk production in the state of Pará, Brazil, 2017

\begin{tabular}{l|c|c|c|c|c}
\hline $\begin{array}{l}\text { FU and } \\
\text { country }\end{array}$ & Ranches & $\begin{array}{c}\text { Milked buffaloes } \\
\text { (Heads) }\end{array}$ & $\mathbf{( \% )}$ & $\begin{array}{c}\text { Produced } \\
\text { amount } \\
\text { (Thousand } \\
\text { litters) }\end{array}$ & $(\%)$ \\
\hline Pará & 1,438 & 22,038 & 19.53 & 11,923 & 14.06 \\
Brazil & 4,663 & 112,851 & 100.00 & 84,778 & 100.00 \\
\hline
\end{tabular}

Source: Data from IBGE (2018).

Observation: Data obtained directly from IBGE Center IBGE - Belém on September 16 2018.

The growth analysis of milk production, in Pará and Brazil, reveals that milked buffaloes herd grew from 2006 to 2017. Both Pará and Brazil showed significant growth with GGR of $4.90 \%$ and $8.73 \%$, respectively.

This growth is related to milk quality aspects, as it is more used by the producer to manufacture dairy products, due to the high protein and fat content, which allow the cheese industry to achieve a higher production yield. In addition, its good nutritional characteristics as it contains less cholesterol, high protein content and besides being highly rich in calcium and phosphorus.

\subsection{Rural Credit Analysis in the State of Pará}

The number of rural credit operations and the amount $(\mathrm{R} \$)$, granted to buffalo production enterprises, ranged over the 1995- 2015 period (Graph 1). 


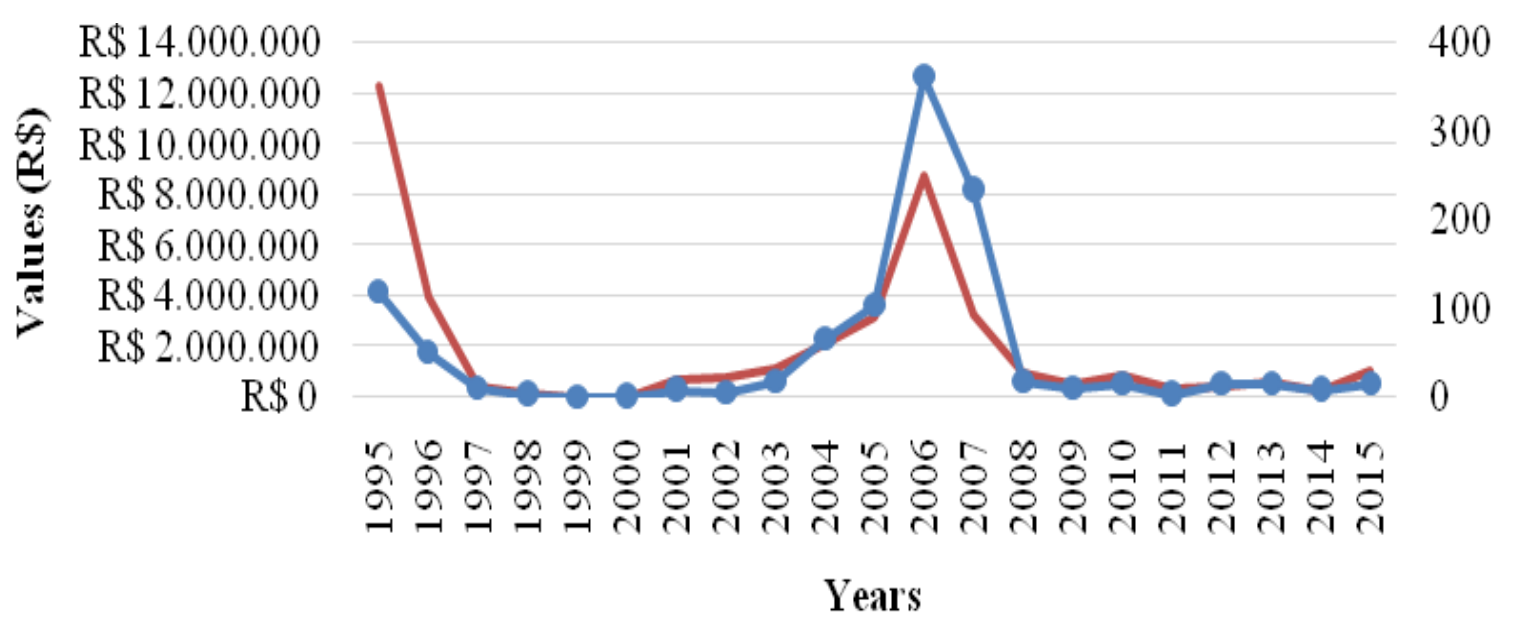

$\longrightarrow$ Values $\rightarrow-\mathrm{N}^{\circ}$ buffalo operations

Graph1. Quantitative behavior of rural credit operation for buffaloes in the state of Pará in the1995-2015 period

Source: BACEN, 2018.

Observation: Prices deflated for July 2018.

Graph 1 shows that the largest concentration of operations number carried out was in the 2004-2007 period. This increase was accentuated in 2006, when an amount of $\mathrm{R} \$ 8,805,030.11$ was applied to the activity, accounting for $0.74 \%$ of the total rural credit operations carried out in the state over the studied period.

The rural credit expansion for buffalo breeding in 2004-2007 period is related to increased demand for pasture cattle production. This search was caused by the outbreak of Bovine Spongiform Encephalopathy (BSE) disease in Europe, known as mad cow disease, which is caused by a protein form called prion. The disease spread in animals subjected to feedlot systems in Europe, where cattle were fed animal protein. This eventually severely restricted its marketing and thus, it contributed to boosting pasture production and livestock activities in the Amazon.

The operations number has decreased since 2007, reaching only 16 in 2015 at the amount of BRL1,052,713.19, about $0.04 \%$ of the total operations value carried out using rural credit. This decrease reflects the lack of organization of the buffalo breeding in the state, which is considered as an income secondary source in many ranches.

Despite having the largest herd in the country, with $0.76 \%$ GGR of the increase in herd in the period from 1996 to 2016, farmers require few resources from rural credit to perform the activity, even further restricting themselves in the analyzed period when GGR of credit operations fell by about $9.6 \%$.

Regarding the operations values, it was observed that, between 1995 and 2002, the value 
gradually decreased. However, it is observed that this amount had increased from 2003 until reaching its highest value in the entire studied period in 2006. However, in the following years, the operations number decreased until 2017, maintaining small oscillations until 2015 as shown in Graph 1.

\subsection{Analysis of the Real Price (R\$/@) of Buffalo Meat in the State of Pará}

Despite being little widespread in Brazil, this food is highly appreciated by the public who consumes traditional dishes or barbecue, but unfortunately many meat-packing plants pay less for it than for cattle, precisely because the production is not promoted (Silva; Nardi Junior, 2014).

Buffalo meat is traded in most parts of the country without a definite form of identifying its characteristics, mainly the nutritional quality to human health or fair value (Jorge et al., 2005). The arroba real price behavior of buffalo meat from 2005 to 2018 is shown in Graph 2.

The prices (R\$/@) oscillated in 2005- 2012 period, which involved the activity cycles. Over the course of 13 years, no trend on the rise in the prices was found (Graph 2).

A sharp increase was identified in 2006- 2008 period, followed by a continuous drop until 2010 , with recovery in the following year, remaining stable until mid-2012, showing an accelerated increase from 2013 to 2017 (Graph 2).

These fluctuations in price are related to the production behavior in the state, where it can be observed that, in periods when there was greater availability of the product in the market, the price decreased, according to the law of supply and demand.

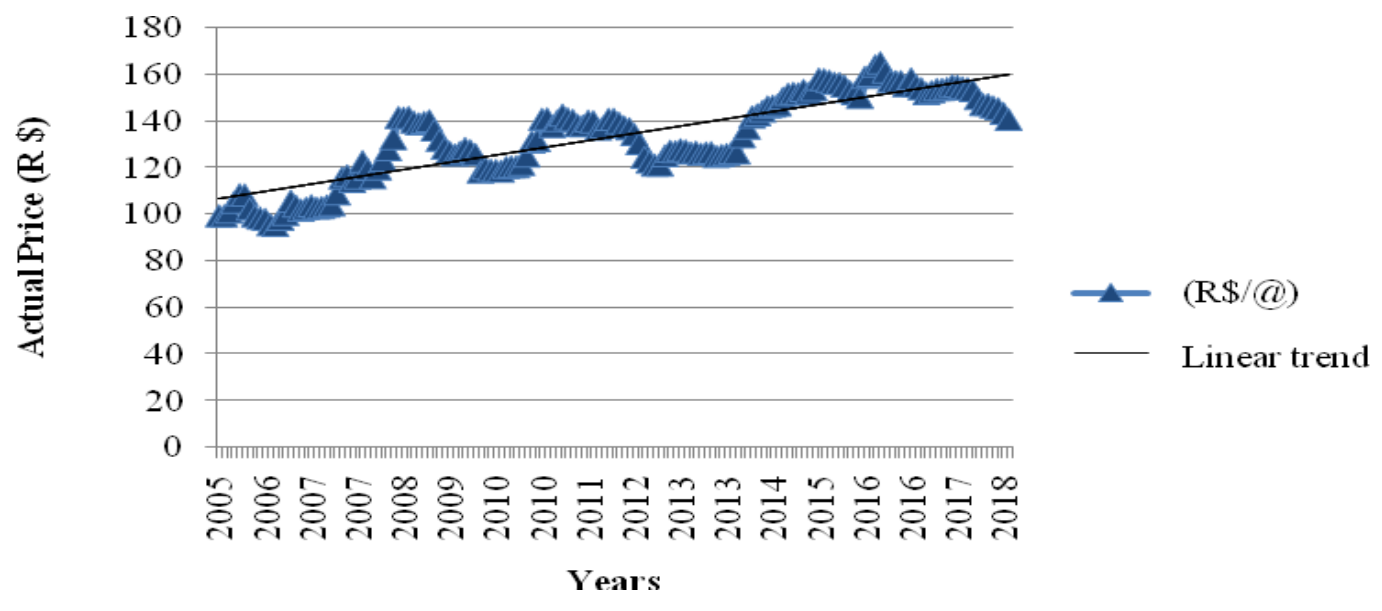

Graph 2. Trend on the real buffalo meat price (R \$/@) from 2005 to 2018

Source: research data, 2018.

Observation: Prices deflated for July 2018. 


\subsection{Price Seasonal Index}

Price behavior exhibits the seasonal characteristic that defines how price behaves throughout the year (Graph 3).

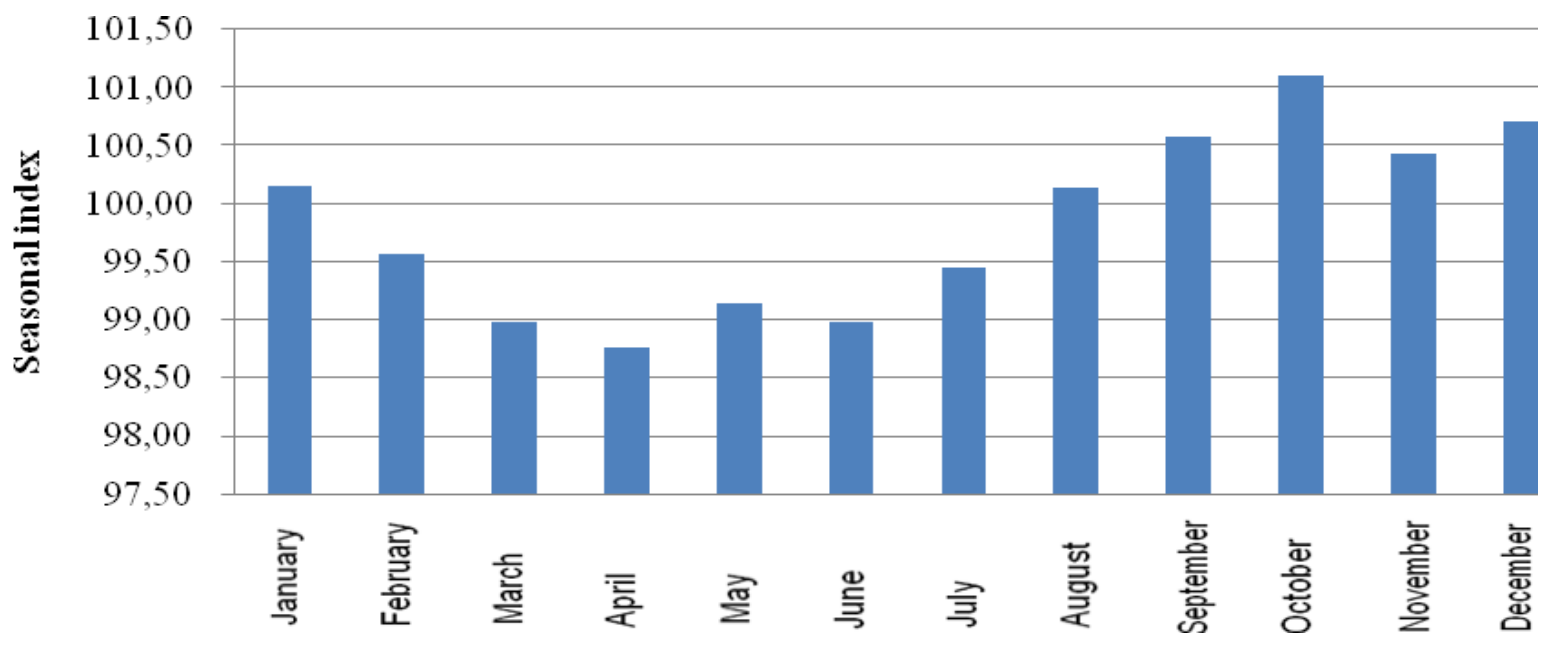

Graph 3. Prices seasonal index of buffalo meat in the state of Pará from 2006 to 2018

Source: Research data, 2018.

From January onwards, prices gradually decreased reaching the lowest values in March, April, May and June months, a period when there was a strong climate influence due to rainfall in the region, resulting in higher forage production and therefore, in a greater supply of food and weight gain in animals, expanding its supply and causing a reduction in the market price.

From August to December, prices reach the highest values due to the lower offer of the product in the market. Producers specialized in the buffalo production stand out because it is during this period where they invest in animal nutrition, through supplementation to meet the nutritional need, producing animals ready for slaughter at the time of the greatest appreciation.

\section{Conclusion}

Despite having the largest herd in Brazil, the state of Para does not stand out as the largest producer of buffalo meat in the country. This is related to the clandestinity, in which buffalo market is involved in the state, where many animals are traded as bovine.

Buffalo milk production in Pará is characterized by small farmers, with extensive production, resulting in low productivity. However, its main by-product, Marajó cheese, has great regional appeal and it is highly accepted in the market.

The buffalo price $(\mathrm{R} \$ / @)$, in Para, showed characteristics of cycles, with some oscillations over the last decade (2006 - 2016), but it tended to grow over the period.

The demand for rural credit for buffalo breeding, in Pará, is still not significant. According to the study, in the last 20 years, rural credit was concentrated in the period from 2004 to 2007, 
when the highest demands occurred. This scenario suggests that the activity is still little economically explored in the region, and that many producers do not use this type of incentive to boost production in the state. It can be inferred that, there is a need for greater technical support to assist the buffalo farmers in Pará.

The study finds that buffalo breeding in Pará does not have proper structure and adequate organization to leverage the activity in "paraense" territory, even though it has the biggest buffalo breeding in the country, good animal adaptation to region's environmental conditions and local breeders interest in the activity.

The growth and consolidation of the buffalo production chain in the Pará's economy will depend on: i) the implementation of improvements in the production system, based on nutritional management, using quality pasture and adequate supplementation aiming the productivity increase; ii) expansion of technical assistance and rural extension services with small producers to appropriate the existing technologies; and iii) investment in advertisement to highlight the qualities of buffalo products for human health, as a way to increase their consumption in the region. In addition, Table 2 shows that Itaituba, São Felix do Xingu, Parauapebas and Altamira micro-regions had the highest GGR in the state. Almerim stood out among the three largest producing meso-regions regarding the herd increase, showing a growth rate of $3.79 \%$ per year over the analyzed period. Arari meso-region did not show any significant growth.

\section{Acknowledgement}

The authors are grateful to Beatriz Cordeiro Costa e Isabel Valença, for the English version revision of the article and to Prof. Dr. João Batista Padilha Junior, for the critical reading of the text in its original version.

\section{References}

AGÊNCIA DE DEFESA AGROPECUÁRIA DO ESTADO DO PARÁ - ADEPARÁ (2011). Lei $n^{\circ} 7.565$, de 25 de outubro de 2011 .

Amaral, F. R., \& Escrivão, S. C. (2005). Aspectos relacionados à búfala leiteira. Revista Brasileira de Reprodução Animal, 29, 111-117.

BANCO CENTRAL DO BRASIL (BACEN). Cotações e Boletins. Disponível em: < https://www4.bcb.gov.br/pec/taxas/port/ptaxnpesq.asp?frame=1>. Acesso em: 10 aug. 2018.

Barbosa, N. G. S. (2005). Bubalinocultura no Estado do Pará. Revista Brasileira de Reprodução Animal, 29, 34-38.

Bernardes, O. (2007). Bubalinocultura no Brasil: situação e importância econômica. Revista Brasileira de Reprodução Animal, 31, 293-298.

Damé, M. C. F. (2006). Búfalo: animal de tração. Pelotas: Empresa Brasileira de Pesquisa Agropecuária. 24p.

FUNDAÇÃO GETULIO VARGAS - FGV. (2018). FGVDADOS: Informação Econômica 


\section{Macrothink}

On-line. Disponível em: < http://fgvdados.fgv.br >. Acesso em: 10 agos. 2018.

Gujarati, D. N., \& Porter, D. C. (2011). Econometria básica. 5 ed. Porto Alegre: McGraw Hill-Bookman, 920p.

Hoffmann, R. (1991). Estatística para economistas. São Paulo: Pioneira, 379 p.

INSTITUTO BRASILEIRO DE GEOGRAFIA E ESTATÍSTICA - IBGE. (2006). Censo Agropecuário. Disponível em: https://sidra.ibge.gov.br/tabela/959. Acesso em: 05 jun. 2018.

INSTITUTO BRASILEIRO DE GEOGRAFIA E ESTATÍSTICA - IBGE. (2018): Produção da Pecuária Municipal. Disponível em: https://www.ibge.gov.br/estatisticas -novoportal/economicas/agricultura-e-pecuaria/9107-producao-da-pecuaria-municipal.html?= $\& \mathrm{t}=\mathrm{o}$-que-e. Acesso em: 05 jun. 2018

Jorge, M. A, Andrighetto, C., Strazza, M. R. B, Correa, R. C, Kasburgo, D. G, Piccinin, A., Victória, C., \& Domingues, P. F. (2005). Correlação entre o California Mastitis Test (CMT) e a Contagem de Células Somáticas (CCS) do Leite de Búfalas Murrah. Revista Brasileira de Zootecia, 34, 2039-2045. https://doi.org/10.1590/S1516-35982005000600029

Lourenço Júnior, J. B., \& Garcia, A. R. Panorama da bubalinocultura na Amazônia. 2008. Disponível em: <https://www.alice.cnptia.embrapa.br/alice/bitstream/doc/409969/1/ LOURENCO2008 AmazonpecPanorama.pdf>. Acesso em: 27 maio 2018.

Mendes, J. T. G., \& Padilha Junior, J. B. (2007). Agronegócio: Uma Abordagem Econômica. São Paulo: Pearson Prentice Hall. 370p.

Negri Neto, A., Coelho, P. J., \& Moreira, I. R. O. (1993). Análise gráfica e taxa de crescimento. Informação Economica, 23, 99-108.

Raiol, L. C. B., Santos, M. A. S., \& Rebello, F. K. (2009). Fontes de crescimento da pecuária leiteira no Nordeste Paraense no período de 1990 a 2007. Revista Mov. Id., XV. 1, 37-55.

Silva, S. L., \& Nardi Junior, G. (2014). Produção de derivados bubalinos e mercado consumidor. Tek.e Log., 5, 15-30.

Thiruvenkadan, A. K., Rajendran, R., \& Muralidharan, J. (2013). Buffalo Genetic Resources of India and Their Conservation. Revista Buffallo Bill, 32, 227-235.

\section{Copyright Disclaimer}

Copyright for this article is retained by the author(s), with first publication rights granted to the journal.

This is an open-access article distributed under the terms and conditions of the Creative Commons Attribution license (http://creativecommons.org/licenses/by/4.0/). 